\title{
Compaction Characteristics of Municipal Solid Waste
}

\author{
James L. Hanson, Ph.D., P.E., M.ASCE${ }^{1}$; Nazli Yesiller, Ph.D., A.M.ASCE'; Shawna A. Von Stockhausen, \\ P.E., M.ASCE ${ }^{3}$; and Wilson W. Wong, A.M.ASCE ${ }^{4}$
}

\begin{abstract}
Compaction characteristics of municipal solid waste (MSW) were determined in the laboratory and in the field as a function of moisture content, compactive effort, and seasonal effects. Laboratory tests were conducted on manufactured wastes using modified and 4X modified efforts. Field tests were conducted at a MSW landfill in Michigan on incoming wastes without modifications to size, shape, or composition, using typical operational compaction equipment and procedures. Field tests generally included higher efforts and resulted in higher unit weights at higher water contents than the laboratory tests. Moisture addition to wastes in the field was more effective in winter than in summer due to dry initial conditions and potential thawing and softening of wastes. The measured parameters in the laboratory were $\gamma_{d \text { max-mod }}=5.2 \mathrm{kN} / \mathrm{m}^{3}, w_{\text {opt-mod }}=65 \%, \gamma_{d \max -4 \times \bmod }=6.0 \mathrm{kN} / \mathrm{m}^{3}$, and $w_{\text {opt }-4 \times \bmod }=56 \%$; in the field with effort were $\gamma_{d \text { max-low }}=5.7 \mathrm{kN} / \mathrm{m}^{3}, \quad w_{\text {opt-low }}=70 \% ; \gamma_{d \text { max-high }}=8.2 \mathrm{kN} / \mathrm{m}^{3}$, and $w_{\text {opt-high }}=73 \% ;$ and in the field with season were $\gamma_{d \text { max-cold }}$ $=8.2 \mathrm{kN} / \mathrm{m}^{3}, w_{\text {cold }}=79.5 \%, \gamma_{d \text { max-warm }}=6.1 \mathrm{kN} / \mathrm{m}^{3}$, and $w_{\text {warm }}=70.5 \%$. Soil compaction theory was reasonably applicable to wastes with the exception that the $G_{s}$ of waste solids increased with compactive effort resulting in steep degree of saturation curves and low change in $w_{\text {opt }}$ between efforts. Moisture addition to wastes during compaction increased the workability, the unit weight, and the amount of incoming wastes disposed, and reduced the compaction time. The combined effects have significant environmental and economic implications for landfill operations.
\end{abstract}

\section{Introduction}

The majority of municipal solid waste (MSW) generated in the United States is disposed of in landfills. In 2007, MSW disposal at a total of 1,754 landfills amounted to 124 million tons representing $54 \%$ of wastes generated in the United States (U.S. EPA 2009). In general, the amount of wastes generated and disposed in landfills on an annual basis increases despite source reduction and recycling efforts. The infrastructure for MSW containment has consolidated considerably over recent decades with increased size and decreased number of operational facilities. Permitting and construction of new landfill facilities are becoming increasingly difficult due to the scarcity of suitable sites as well as public resistance. Optimizing landfill capacity is significant for extending service life of existing facilities and reducing the need for new landfill construction.

Compaction of wastes at a landfill is the main factor that controls short-term density and resulting placement efficiency of wastes in the landfills. Maximizing waste density allows to reduce

${ }^{1}$ Professor, Civil and Environmental Engineering Dept., California Polytechnic State Univ., San Luis Obispo, CA 93407

${ }^{2}$ Director, Global Waste Research Institute, California Polytechnic State Univ., San Luis Obispo, CA 93407.

${ }^{3}$ Engineer II, Hatch Mott MacDonald, Pleasanton, CA 94588.

${ }^{4}$ Staff Engineer, Hultgren-Tillis Engineers, Concord, CA 94520. landfill space requirements or to prolong the life of a facility (Ham et al. 1978). Density influences the stability of a landfill with high densities generally associated with high shear strengths. Combined moisture-density characteristics influence hydraulic response and compressibility of wastes. Overall, the as-placed moisture-density characteristics of MSW are critical for both operation of landfills and engineering response of wastes.

Field compaction of MSW includes use of procedures and equipment similar to those for soil compaction. For wastes, compaction equipment is generally larger, heavier, and has larger pad feet or teeth than the equipment used for soils. Compaction is done in lifts and with multiple passes over a given area on asreceived wastes. Practical qualitative recommendations for field compaction of MSW include: uniform lifts, thin lifts, and provisions for inspection and sampling (Fang 1997). Data have been provided for unit weight and moisture content of wastes in landfills. However, systematic studies of field compaction of wastes have not been conducted and paired unit weight-moisture content values immediately after compaction generally are not available on a field scale. The total unit weight of wastes compacted in test cells varied between 3.8 and $5.5 \mathrm{kN} / \mathrm{m}^{3}$ at a landfill in Wisconsin (Ham et al. 1978). The wastes were compacted with equipment significantly lighter than the currently available waste compactors. The variations in unit weight were attributed to variations in waste moisture content with seasons (high moisture content and unit weight in spring/summer and low moisture content and low unit weight in fall/winter). Emphasis in literature has been placed on the determination of distribution of unit weight and moisture content with depth and waste age. Even though compaction controls the efficient use of the disposal capacity and stability in a landfill, well-developed guidelines are not available for field com- 
paction practices. Specifications and quality control practices are not used for wastes.

Similarly, limited information is available on laboratory compaction of MSWs, in particular for fresh wastes. Common soil testing procedures were used for fresh wastes in geotechnical investigations of waste characteristics in two studies. Tests were conducted on wastes obtained from landfills in England (Harris 1979). Standard effort tests resulted in average $7.1 \mathrm{kN} / \mathrm{m}^{3}$ maximum dry unit weight and 58\% optimum moisture content. Harris (1979) indicated that the moisture content of incoming fresh wastes typically varied as a function of weather conditions between 20 and $50 \%$ and that water addition during compaction would aid in compaction to obtain a denser fill and for maximum amount of waste placement in a given landfill volume. Tests were conducted on fresh wastes obtained from a landfill in Illinois (Reddy et al. 2009). Standard effort tests resulted in $4.1 \mathrm{kN} / \mathrm{m}^{3}$ maximum dry unit weight and $70 \%$ optimum moisture content. Geotechnical testing procedures were also used for determining compaction characteristics of old wastes in the laboratory as reported by Harris (1979), Gabr and Valero (1995), Itoh et al. (2005), and Reddy et al. (2009). The majority of these tests were conducted using compactive efforts similar to standard effort.

This study was conducted to determine compaction characteristics of MSW both in the laboratory and in the field. Effects of environmental (seasonal variation and temperature) and operational (moisture content, compactive effort, and compaction duration) conditions on compaction were investigated. Mechanisms of waste compaction were analyzed. Practical implications also were assessed.

\section{Laboratory Testing Program}

Laboratory compaction tests were conducted on manufactured waste samples prepared using MSW constituent compositions provided by U.S. EPA (2008): $24 \%$ paper and paperboard, $18 \%$ food, $16 \%$ plastics, $7 \%$ yard waste, $7 \%$ wood, $7 \%$ metals, $6 \%$ glass, $6 \%$ textiles, $3 \%$ rubber and leather, $4 \%$ inorganic waste, and $2 \%$ other wastes. The maximum dimensions of the constituents were limited to nominally $20 \mathrm{~mm}$ for bulky materials and 50 $\mathrm{mm}$ for fibrous and flexible planar materials. The initial natural moisture content of the manufactured wastes varied between 9 and $12 \%$ (gravimetric on a dry solids basis). Manufactured wastes were used instead of fresh wastes obtained from a landfill to provide representative yet relatively homogeneous specimens. Factors that affect compaction were investigated without the influence of compositional variability between specimens, which allowed for representative yet repeatable tests. In addition, testing on manufactured wastes alleviated health and safety concerns associated with the use of large quantities of fresh wastes in a laboratory setting.

Procedures used for testing soils were adopted for the laboratory investigation. Tests were conducted using two levels of compaction energy: modified effort (ASTM D1557) and four times (4X) modified effort to simulate high field efforts while still maintaining the framework of a standardized test method. High levels of compactive efforts were selected for the tests, as the writers believe that high energy is required to represent field compaction of wastes based on their observations of field conditions. Standard effort does not sufficiently represent field compaction. Moisture content of the specimens varied between 11 and $141 \%$ in modified effort tests and 9 and $126 \%$ in $4 \mathrm{X}$ modified effort tests to represent relatively dry and wet waste conditions. All of the tests were conducted using a 152-mm diameter compaction mold and five lifts. The number of blows per lift was adjusted to 224 blows to apply the $4 \mathrm{X}$ modified effort. The total number of specimens tested was 19 and 17 for modified and $4 \mathrm{X}$ modified tests, respectively.

Water was added to the wastes using two different methods. In the first approach [prewetted (PW) tests], the required amount of water was added to the manufactured wastes to reach the target moisture content for a given specimen. The loose specimens were allowed to hydrate for 16 to $24 \mathrm{~h}$ prior to compaction. This approach simulated typical laboratory soil compaction procedures. In the second approach [non-PW (NPW) tests], water was added to the manufactured wastes to bring the moisture content to $30 \%$ and the loose specimens were allowed to hydrate for 16 to $24 \mathrm{~h}$. Subsequent to hydration, extra water for higher target moisture contents were added to the loose specimens and the specimens were compacted immediately without further hydration time. The second approach was used for tests at moisture contents $\geq 30 \%$. The NPW tests represented water addition to wastes in the field (described further below) and also allowed for the investigation of the effects of hydration time on compaction. The 30\% moisture content was selected as this value represented the low seasonal average moisture content of incoming wastes at the field site. In modified effort tests, 9 PW and 10 NPW specimens were used. In $4 \mathrm{X}$ modified effort tests, 8 PW and 9 NPW specimens were used.

\section{Field Testing Program}

The field testing program consisted of determination of compaction characteristics of wastes in a test area at a MSW landfill using the common equipment and procedures employed at the site. Similar to laboratory tests, effects of compactive effort and moisture content on compaction characteristics were investigated. In addition, seasonal effects were analyzed.

\section{Test Site and Operations}

The study was conducted at a Subtitle D MSW landfill in Michigan. The landfill has a permitted disposal capacity of 17.8 million $\mathrm{m}^{3}$. The annual and daily waste disposal amounts are 6,200,000 and 26,000 kN, respectively. The landfill has been operational since 1968 with an estimated closure date of 2027. Under routine operational conditions, wastes are delivered to a compaction area (referred to as working face), are spread into a uniform layer with an approximate thickness of $0.5 \mathrm{~m}$, and compacted by two waste compactors that make several passes over the loose wastes. The working face has an approximate area of $1,400 \mathrm{~m}^{2}$. The waste compactors (BOMAG BC1172RB) each weigh $530 \mathrm{kN}$.

A commercially available global positioning system (GPS) setup (GeoLogic Solutions) is used to control compaction operations. A compactor operator monitors the change in the elevation of the waste surface relative to the previous pass over the waste on a computer screen located in the cab of the compactor. The operator monitors status in real time with a color-coded topographic map. Vertical displacement is monitored over $1.5 \mathrm{~m}$ by $1.5 \mathrm{~m}$ square cells in a grid assigned to the site. Significant compaction of the waste for a cell in the grid is assumed to cease when the vertical displacement for two consecutive passes is less than the threshold set at $120 \mathrm{~mm}$. The operator then moves to the next location in the grid to continue compaction. A location point is recorded each time the compactor crosses a cell boundary to 

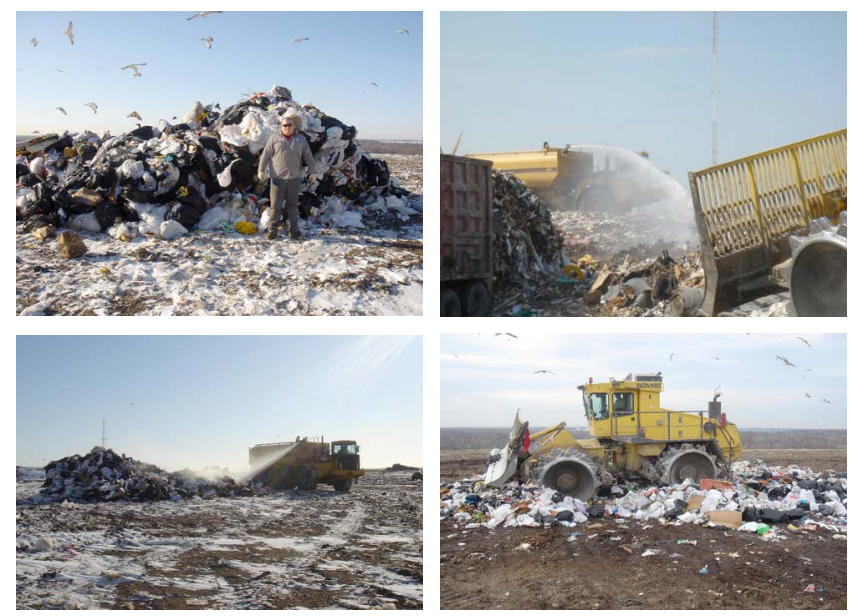

Fig. 1. Photographs of compaction test plot: placement of wastes, water addition to test plot, and compaction

build a compacted waste surface. The volume filled by the compacted waste during the current operational session is determined as the difference between the surface developed for the preceding and the current operational sessions with 1-day intervals. The weight of wastes is obtained from data collected at scales upon entry of waste trucks into the landfill. Compacted unit weights are determined using the weight of wastes (from scale house records) and volume of wastes (from GPS records).

Baseline compaction characteristics (moisture content and unit weight) resulting from normal operation at the landfill were established by collecting data at the site and using site records. Seasonal and operational variability were determined. The asreceived moisture contents were determined by sampling the incoming wastes at the working face of the landfill in December 2005 and June 2006 over multiple days. Moisture content specimens with masses between 1 and $3.2 \mathrm{~kg}$ were collected to conduct approximately four moisture content tests each day. Waste samples were oven dried at 100 to $105^{\circ} \mathrm{C}$. The number of moisture content tests was 28 and 16 for winter and summer conditions, respectively. The baseline moisture contents were assumed to be applicable throughout the testing program for a given season. Scale house and GPS records from more than 200 individual days of operation between February 2005 and May 2007 were used to determine baseline compacted unit weights.

\section{Field Tests}

The full-scale field compaction tests were conducted over a designated test area (test plots each with an area of approximately $200 \mathrm{~m}^{2}$ ) on level ground above a soil interim cover that provided a firm base in Cell 2 at the landfill (Fig. 1). The average weight of the wastes used for a test was $335 \mathrm{kN}$ (as determined at the scale house). Typical incoming MSWs at the landfill were used in the test program with no modifications to composition, size, or shape. Loads of exclusively curbside wastes from residential properties were used in the test program. Wastes were compacted in the test plots using one waste compactor at a time. The topographic surface in a test plot prior to a compaction test and subsequent to the completion of the test were both established using the GPS setup. The compacted volume was determined using the difference between the initial and final surfaces. A total of 11 tests was conducted in the field test program.
Seasonal effects on compaction were investigated by conducting tests at different times of the year. Seven tests were conducted in December to March representing cold weather conditions and four tests were conducted in May to July representing warm weather conditions. Air temperature was obtained for all of the tests using a weather station at the site.

Effects of operational conditions on compaction were investigated by varying moisture content at a given season and by monitoring compaction conditions including compactor distance traveled and duration of compaction for all tests. For each season, one test was conducted at the initial as-received moisture conditions. The remaining tests were conducted at moisture contents higher than the as-received conditions. Predetermined quantities of water were sprayed on the wastes in the test plot using a turret nozzle on a water truck to achieve target moisture contents. The truck moved and the water pressure was adjusted to apply water uniformly to the waste mass. For each test, total distance traveled and duration of compaction required to complete the test (i.e., achieve vertical displacement $<120$-mm criterion) were monitored. Compaction index was defined for use in the test program as an indicator of compactive effort

$$
E=\frac{W D}{V}
$$

where $E=$ compaction index in $\mathrm{kJ} / \mathrm{m}^{3} ; W=$ weight of compactor in $\mathrm{kN} ; D=$ distance traveled in a test in $\mathrm{m}$ (from GPS data); and $V$ $=$ volume of waste in $\mathrm{m}^{3}$ (from GPS data).

Three distinct unit weights were used in the analysis of compaction characteristics of wastes: dry unit weight $\left(\gamma_{d}\right)$, operational unit weight $\left(\gamma_{\text {oper }}\right)$, and total unit weight $\left(\gamma_{t}\right)$. The definitions for dry and total unit weights are similar to those used in geotechnical engineering. The operational unit weight is determined using solely the weight of incoming wastes (solids and natural moisture) without including the added water (if used). Incoming weight of wastes was determined from scale house records. Total weight was determined by summing the initial weight of wastes and the weight of any water added to the wastes in a compaction test. Volumes were determined using GPS data. The operational and total unit weights are the same for the tests when no water is added to the wastes during compaction. The total and dry unit weights are applicable to engineering calculations, whereas operational unit weight is introduced to evaluate landfill capacity and economic aspects of landfill disposal in practice. The operational unit weight is critical to estimate disposal volume available at a landfill for incoming wastes. The weight of incoming wastes is critical for landfill operations as financial determinations are made based on the tipping fees charged for the wastes by weight upon entry to the landfill

$$
\gamma_{d}=\frac{\text { Weight of Solids }}{\text { Total Compacted Volume }}
$$

$$
\gamma_{\text {oper }}=\frac{\text { Weight of Incoming Wastes }}{\text { Total Compacted Volume }}
$$

$$
\gamma_{t}=\frac{\text { Weight of Incoming Wastes }+ \text { Additional Water }}{\text { Total Compacted Volume }}
$$




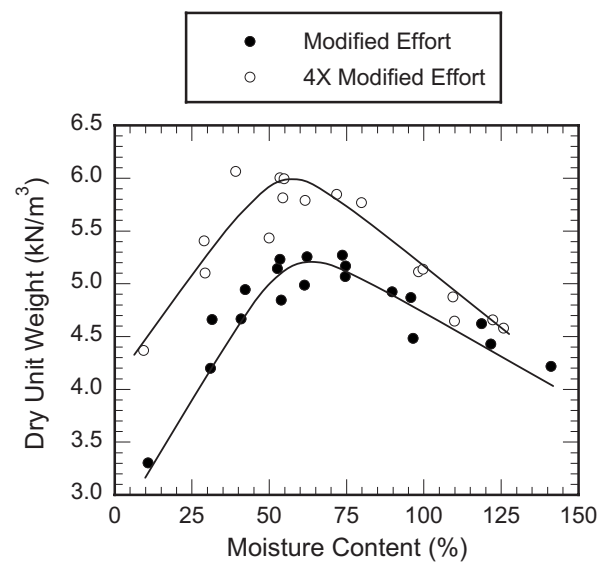

Fig. 2. Laboratory compaction data

\section{Results and Discussion}

\section{Laboratory Compaction Tests}

The results of the laboratory test program for moisture content $(w)$ versus dry unit weight $\left(\gamma_{d}\right)$ relationships are presented in Fig. 2. Results from all tests (PW and NPW) are presented for each compaction effort. The compaction curves are bell shaped for both efforts similar to compaction curves for soils. Dry unit weight varied somewhat less with water content at the wet of optimum moisture contents than the dry of optimum moisture contents. The maximum dry unit weight $\left(\gamma_{d \max }\right)$ was determined to be $5.2 \mathrm{kN} / \mathrm{m}^{3}$ and the optimum moisture content $\left(w_{\text {opt }}\right)$ to be $65 \%$ for the modified effort test. The $\gamma_{d \max }$ was determined to be $6.0 \mathrm{kN} / \mathrm{m}^{3}$ and the $w_{\text {opt }}$ to be $56 \%$ for the $4 \mathrm{X}$ modified effort test. The variation in optimum moisture content between the two efforts (i.e., 9\%) is relatively low with respect to the wide range of moisture contents required to generate the compaction curves.

The compaction characteristics from PW and NPW tests were generally similar for a given effort with one exception where a $5 \%$ difference was present in the $w_{\text {opt }}$ in the modified effort tests between the PW and NPW specimens. The goodness of fit in compaction curves as measured by third order polynomial fits to the compaction data indicated that (1) curve fits to PW specimens were better than the fits to NPW specimens as measured using $R^{2}$ values and (2) the variation in $R^{2}$ values between PW and NPW tests were higher in modified effort tests than in $4 \mathrm{X}$ modified effort tests. Overall, a hydration period of 16 to $24 \mathrm{~h}$ appears appropriate for compaction testing of wastes. Additional detail for PW and NPW tests are provided in Wong (2009).

Operational unit weights were determined for NPW tests by assuming that the wastes prepared at the nominal 30\% moisture content in the laboratory represented the incoming wastes at the field scale. The $w$ versus $\gamma_{\text {oper }}$ relationship was bell shaped similar to the $w$ versus $\gamma_{d}$ relationship (Wong 2009). The initial operational unit weights $\left(\gamma_{\text {oper-initial }}\right)$ were $6.1 \mathrm{kN} / \mathrm{m}^{3}$ (at a water content of $31 \%$ ) and $6.6 \mathrm{kN} / \mathrm{m}^{3}$ (at a water content of $29 \%$ ) for modified and $4 \mathrm{X}$ modified effort tests, respectively. The maximum operational unit weights $\left(\gamma_{\text {oper-max }}\right)$ were determined to be $6.9 \mathrm{kN} / \mathrm{m}^{3}$ (at a water content of $67 \%$ ) and $7.9 \mathrm{kN} / \mathrm{m}^{3}$ (at a water content of $58 \%$ ) for modified and $4 \mathrm{X}$ modified effort tests, respectively. The water contents for $\gamma_{\text {oper-max }}$ were similar to the $w_{\text {opt }}$.

\section{Baseline Field Conditions}

The baseline incoming waste moisture contents were determined to be $31 \%$ for cold winter conditions and $53 \%$ for warm summer conditions. Moisture content was directly affected by climatic conditions and seasonal waste stream. The total monthly precipitation was 57 and $100 \mathrm{~mm}$ for December 2005 and June 2006, respectively. Similar differences in incoming waste moisture content due to weather conditions/seasonal variations were reported for landfills in Wisconsin and England by Ham et al. (1978) and Harris (1979), respectively. Visual observation of waste during winter indicated a large amount of packaging and other dry materials, whereas a large quantity of food waste was observed during summer. The average total/operational unit weight was determined to be $6.5 \mathrm{kN} / \mathrm{m}^{3}$ at the site based on analysis of site records. The average dry unit weight was calculated to be $4.8 \mathrm{kN} / \mathrm{m}^{3}$.

\section{Field Compaction Tests}

A summary of field tests including test variables and test results is presented in Table 1. The data are presented by season and with increasing moisture content in a given season. The moisture contents in the tests varied between 30.6 and $107.2 \%$. The highest measured dry unit weights and corresponding moisture contents

Table 1. Field Tests

\begin{tabular}{|c|c|c|c|c|c|c|c|c|c|c|c|c|c|}
\hline Test & Date & $\begin{array}{l}\text { Air } \\
\text { temperature } \\
\left({ }^{\circ} \mathrm{C}\right)\end{array}$ & $\begin{array}{l}\text { Weight } \\
\text { of } \\
\text { incoming } \\
\text { waste } \\
(\mathrm{kN})\end{array}$ & $\begin{array}{l}\text { Weight } \\
\text { of } \\
\text { existing } \\
\text { water } \\
(\mathrm{kN})\end{array}$ & $\begin{array}{l}\text { Weight } \\
\text { of } \\
\text { water } \\
\text { added } \\
(\mathrm{kN})\end{array}$ & $\begin{array}{c}\text { Weight of } \\
\text { dry } \\
\text { waste } \\
(\mathrm{kN})\end{array}$ & $\begin{array}{l}\text { Volume } \\
\text { of } \\
\text { compacted } \\
\text { waste } \\
\left(\mathrm{m}^{3}\right)\end{array}$ & $\begin{array}{l}w \\
(\%)\end{array}$ & $\begin{array}{c}\gamma_{d} \\
\left(\mathrm{kN} / \mathrm{m}^{3}\right)\end{array}$ & $\begin{array}{c}\gamma_{\text {oper }} \\
\left(\mathrm{kN} / \mathrm{m}^{3}\right)\end{array}$ & $\begin{array}{c}\gamma_{t} \\
\left(\mathrm{kN} / \mathrm{m}^{3}\right)\end{array}$ & $\begin{array}{c}\text { Test } \\
\text { duration } \\
\text { (min) }\end{array}$ & $\begin{array}{c}\text { Compaction } \\
\text { index } \\
\left(\mathrm{kJ} / \mathrm{m}^{3}\right)\end{array}$ \\
\hline 1 & December 11, 2006 & 10 & 377.3 & 88.4 & 0.0 & 288.9 & 68.0 & 30.6 & 4.3 & 5.6 & 5.6 & 6.33 & 2,698 \\
\hline 2 & January 23, 2007 & -3.9 & 334.7 & 78.4 & 37.1 & 256.3 & 41.1 & 45.1 & 6.2 & 8.2 & 9.1 & 4.90 & 24,031 \\
\hline 3 & February 15, 2007 & -5.6 & 249.7 & 58.5 & 74.1 & 191.2 & 37.0 & 69.4 & 5.2 & 6.8 & 8.8 & 8.91 & 4,457 \\
\hline 4 & December 13, 2006 & 7.8 & 296.9 & 69.6 & 111.2 & 227.3 & 27.7 & 79.5 & 8.2 & 10.7 & 14.7 & 5.82 & 34,901 \\
\hline 5 & December 12, 2006 & 7.8 & 361.6 & 84.7 & 148.2 & 276.9 & 36.1 & 84.1 & 7.7 & 10.0 & 14.1 & 3.92 & 26,027 \\
\hline 6 & March 21, 2007 & 0.6 & 325.6 & 76.3 & 185.3 & 249.3 & 42.3 & 104.9 & 5.9 & 7.7 & 12.1 & 5.29 & 23,452 \\
\hline 7 & December 19, 2006 & 5.6 & 378.8 & 88.8 & 222.3 & 290.0 & 72.8 & 107.2 & 4.0 & 5.2 & 8.3 & 8.06 & 2,516 \\
\hline 8 & June 13, 2007 & 31.7 & 409.4 & 142.5 & 0.0 & 266.9 & 54.0 & 53.4 & 4.9 & 7.6 & 7.6 & 6.77 & 3,169 \\
\hline 9 & June 29, 2007 & 24.4 & 331.6 & 115.4 & 37.1 & 216.2 & 35.2 & 70.5 & 6.1 & 9.4 & 10.5 & 6.32 & 3,703 \\
\hline 10 & July 9, 2007 & 27.8 & 256.9 & 89.4 & 74.1 & 167.5 & 37.7 & 97.6 & 4.4 & 6.8 & 8.8 & 5.86 & 5,513 \\
\hline 11 & May 25, 2007 & 27.2 & 350.1 & 121.9 & 111.2 & 228.3 & 45.3 & 102.1 & 5.0 & 7.7 & 10.2 & 5.25 & 3,847 \\
\hline
\end{tabular}




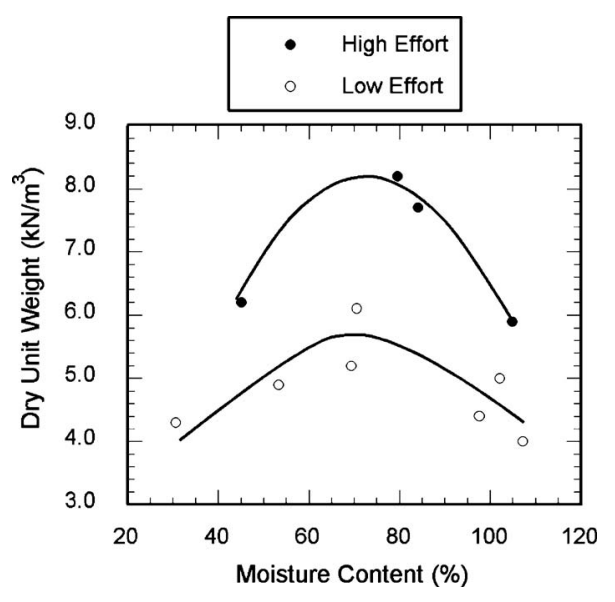

Fig. 3. Compaction data from field test plots

were $8.2 \mathrm{kN} / \mathrm{m}^{3}$ and $79.5 \%$ for cold, and $6.1 \mathrm{kN} / \mathrm{m}^{3}$ and $70.5 \%$ for warm weather conditions, respectively. The operational unit weights at these moisture contents were 10.7 and $9.4 \mathrm{kN} / \mathrm{m}^{3}$ for winter and summer, respectively. Comparison of the maximum unit weights (Tests 4 and 9) with initial conditions for each season (Tests 1 and 8), indicated that the total unit weights increased by 165 and $38 \%$, and the dry and operational unit weights increased by 93 and $24 \%$ due to moisture addition in winter and summer, respectively. Moisture addition was more effective in winter than summer due to the presence of dry initial conditions and some incoming frozen wastes in winter. These conditions resulted in relatively poor baseline compaction in winter without water addition. Softening due to water addition was observed for all of the field tests, but the softening effects in winter were more pronounced than in summer due to warming and partial thawing of frozen wastes. Thawing was visually observed and temperature differences in the range of 15 to $16^{\circ} \mathrm{C}$ were measured between the wastes and added water for frozen wastes (Von Stockhausen 2007).

Compaction curves were generated for field tests (Table 1) for two levels of average compaction index (3,700 and $\left.27,000 \mathrm{~kJ} / \mathrm{m}^{3}\right)$ as presented in Fig. 3. Compaction indices less than $6,000 \mathrm{~kJ} / \mathrm{m}^{3}$ (specifically 2,500 to 5,500 ) were designated as representative of low effort and indices greater than $20,000 \mathrm{~kJ} / \mathrm{m}^{3}$ (specifically 23,000 to 35,000 ) were designated as representative of high effort. The field compaction curves were bell shaped similar to the data obtained in the laboratory as well as to typical soils. The $\gamma_{d \max }$ were 5.7 and $8.2 \mathrm{kN} / \mathrm{m}^{3}$ and the $w_{\text {opt }}$ were 70 and $73 \%$ for the low and high efforts, respectively. Statistical analysis of the variation in compaction characteristics as a function of uncertainty of incoming moisture content of wastes was provided in Von Stockhausen (2007). The maximum dry unit weight increased with increasing compactive effort, whereas the optimum moisture content was relatively similar between the two efforts. Field tests generally resulted in higher unit weights at higher water contents than the laboratory tests, even though at low efforts the laboratory and field data were generally similar (Figs. 2 and 3). The differences may have resulted from the exact mode and level of applied effort and potential differences in the composition of the wastes. Nevertheless, laboratory testing provides an effective means for evaluating compaction characteristics of wastes including values for parameters and trends.

In general, dry unit weight increased with increasing compac-
Table 2. Waste Moisture Conditions

\begin{tabular}{lcccc}
\hline Test & $\begin{array}{c}w(\text { dry basis }) \\
(\%)\end{array}$ & $\begin{array}{c}w(\text { wet basis }) \\
(\%)\end{array}$ & $\begin{array}{c}\theta \\
(\%)\end{array}$ & $\begin{array}{c}\text { Water added } \\
\left(\mathrm{kN} / \mathrm{m}^{3}\right)\end{array}$ \\
\hline 1 & 30.6 & 23.4 & 13.3 & 0 \\
2 & 45.1 & 31.1 & 28.7 & 0.9 \\
3 & 69.4 & 41.0 & 36.6 & 2.0 \\
4 & 79.5 & 44.3 & 66.5 & 4.0 \\
5 & 84.1 & 45.7 & 65.7 & 4.1 \\
6 & 104.9 & 51.2 & 63.1 & 4.4 \\
7 & 107.2 & 51.7 & 43.6 & 3.1 \\
8 & 53.4 & 34.8 & 26.9 & 0 \\
9 & 70.5 & 41.4 & 44.2 & 1.1 \\
10 & 97.6 & 49.4 & 44.3 & 2.0 \\
11 & 102.1 & 50.5 & 52.4 & 2.5 \\
\hline
\end{tabular}

tive effort. The cold weather tests required higher compactive efforts to reach the termination criterion than the warm weather tests. This was attributed to increased stiffness of the wastes at lower temperatures. A linear relationship was proposed to estimate dry unit weight using compaction index at this site.

$$
\gamma_{d}=1 \times 10^{-4} E+4.45
$$

where $\gamma_{d}=$ dry unit weight in $\mathrm{kN} / \mathrm{m}^{3}$ and $E=$ compaction index in $\mathrm{kJ} / \mathrm{m}^{3}$

In general, test duration decreased with increasing moisture content (applicable to the majority of the tests in winter and all of the tests in summer, Table 1). Waste workability was higher at increased moisture contents than at low moisture contents due to soft and uniform waste consistency, which allowed rapid travel by the compactor decreasing compaction duration. Rebound of wastes between passes was observed to be lower at high moisture levels. For high moisture contents, high compactive efforts resulted in time-efficient compaction (i.e., short duration of compaction) of wastes compared to compaction at low efforts. The baseline average dry unit weight for the site $\left(4.8 \mathrm{kN} / \mathrm{m}^{3}\right)$ generally could be obtained with sufficient duration of compaction (greater than approximately $6 \mathrm{~min}$ ) for variable moisture conditions and high compactive effort resulted in short durations (less than approximately $6 \mathrm{~min}$ ). Compaction duration has significant economic impacts for operation of a landfill. If compaction time can be reduced, the equipment requirements (including number of compactors, maintenance costs, operators, greenhouse gas emissions, etc.) can also be reduced. The overall benefits of adding moisture to wastes include increasing workability, increasing unit weight, and reducing the time required for compaction. The combined effects have significant economic implications for landfill operations.

An extended version of the moisture data from the field tests is presented in Table 2. The volumetric moisture contents $(\theta)$ of the wastes for baseline conditions (i.e., $13.3 \%$ for winter and $26.9 \%$ for summer) were relatively low and likely less than field capacity. The volumetric field capacity of MSW was reported to range from 22.4 to $70.6 \%$ with the great majority of the data in the 30 to $55 \%$ range (Qian et al. 2002). Anaerobic decomposition of wastes is optimized at moisture contents at and above the field capacity. Water addition to the wastes in the field tests increased the $\theta$ of the wastes to the 30 to $55 \%$ range for the majority of the tests in winter (except for Test 2) and for all of the tests in summer (Table 2).

In bioreactor landfill applications, $w_{\text {wet }}$ (gravimetric moisture content on wet basis) higher than $25 \%$ up to 40 to $70 \%$ were 
reported to represent optimum conditions without complete saturation (Baker and Eith 2000; Phaneuf 2000). Addition of 1.9 to $3.9 \mathrm{kN}$ and approximately 0.7 to $1.5 \mathrm{kN}$ of water per $\mathrm{m}^{3}$ of MSW was recommended for bioreactor applications by Baker and Eith (2000) and Phaneuf (2000), respectively. Moisture addition in the tests increased the $w_{\text {wet }}$ of the wastes to the 40 to $70 \%$ range for all of the tests except for Test 2 and the amount of added water was in line with the values recommended for bioreactor applications (Table 2).

Moisture addition to wastes during compaction provides an alternative method for introducing leachate, water, or other liquids to wastes for leachate recirculation and bioreactor landfill applications. The spraying method used in this investigation results in relatively uniform moisture delivery at saturation levels below $100 \%$ alleviating the problems associated with typical moisture addition methods whereby liquids are injected into wastes that have reached specific heights using discrete pathways such as vertical wells, horizontal wells, trenches, and blankets (Qian et al. 2002; Haydar and Khire 2007). Typical problems of nonuniform moisture conditions of dry spots or fully saturated locations and short-circuiting of the added moisture through preferential flow paths in the waste mass can be prevented by adding moisture to wastes during compaction.

\section{Applicability of Compaction Theory}

The general shape of the compaction curves obtained for wastes both in the laboratory and in the field was consistent with the shape of compaction curves commonly obtained for soils. Unit weights $\left(\gamma_{d}\right.$ and $\left.\gamma_{\text {oper }}\right)$ increased with water content to a maximum value and then decreased with further increases in moisture content. Similar to soils, the additional solids content per unit volume was attributed to the lubrication of the particles from water addition resulting in a denser packing arrangement. The water addition also produced a softening of the solid materials in wastes, increasing compressibility and decreasing rebound (significant for wastes) in response to compaction forces. The effectiveness of the moisture addition diminished at wet of optimum conditions as indicated by the decreasing $\gamma$ due to the replacement of solids with water. In general, the relative locations of the compaction curves for low and high effort on the $w$ versus $\gamma_{d}$ space were similar to those for soils. For wastes, unit weights increased significantly with increasing effort, whereas the variation in $w_{\text {opt }}$ between different efforts were relatively low, particularly in the field.

The compaction phenomenon observed for wastes is explained with an increase in the unit weight and specific gravity $\left(G_{s}\right)$ of solids in the waste mass with increasing compactive effort. A sharp increase in unit weight occurs with relatively low change in moisture content due in part to an increase in the unit weight of the solids. Potential crushing and reorganization of the internal structure of the solid components of the different materials present in the waste mass under high stresses (i.e., high compactive efforts) leads to increases in the density of the solid matter. Increase in the density of waste solids $\left(\rho_{s}\right)$ was observed in largescale one-dimensional compression tests by Hudson et al. (2004). The $\rho_{s}$ increased from 0.876 to $1.303 \mathrm{Mg} / \mathrm{m}^{3}$ with an increase in average stress from 34 to $463 \mathrm{kPa}$ and associated increase in waste dry density from 0.39 to $0.71 \mathrm{Mg} / \mathrm{m}^{3}$.

The $G_{s}$ for the manufactured waste used in the laboratory tests was calculated to be 1.4 using a weighted average of the $G_{s}$ values for the individual components of the waste mixture obtained from literature (Wong 2009). This value was assumed to be

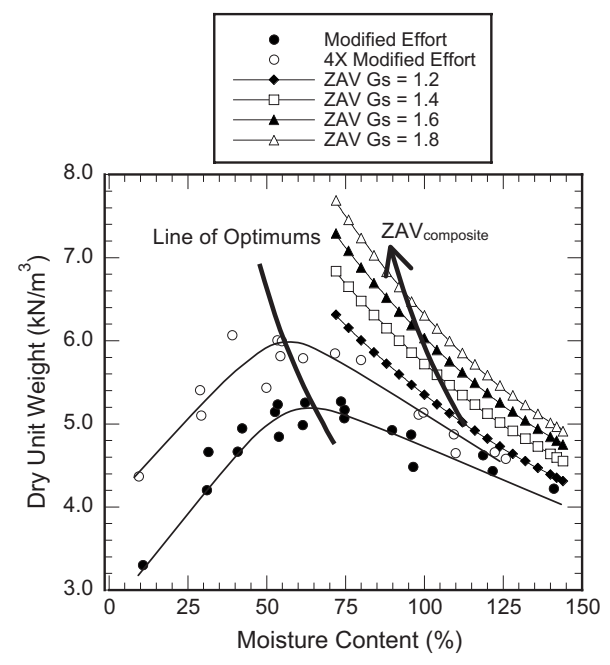

Fig. 4. Laboratory compaction data with variable ZAV curves

valid for the modified effort tests. The degree of saturation for the peak of the compaction curve was determined to be $55.5 \%$ using $w_{\text {opt }}$ of $65 \%$ and $\gamma_{d \max }$ of $5.2 \mathrm{kN} / \mathrm{m}^{3}$. The degree of saturation was assumed to be the same (i.e., $55.5 \%$ ) at the peak of the $4 \mathrm{X}$ modified compactive effort curve along the line of optimums. The $G_{s}$ for this point was back-calculated to be $1.6 \mathrm{using} w_{\mathrm{opt}}$ of $56 \%$ and $\gamma_{d \max }$ of $6.0 \mathrm{kN} / \mathrm{m}^{3}$. $G_{s}$ was also estimated for the $4 \mathrm{X}$ modified effort test using data provided by Hudson et al. (2004) by scaling up the initial $G_{s}$ of 1.4 using dry density. The $G_{s}$ was determined to be 1.55 which was in good agreement with the $G_{s}$ calculated using the line of optimums analysis.

The laboratory compaction data are presented in Fig. 4 with the addition of zero air voids (ZAV) curves for multiple $G_{s}$ values. Unlike soils, the ZAV curve for wastes was not unique for a given compaction test program that included multiple efforts. For wastes, $G_{s}$ increased as the compactive effort increased resulting in (1) the shift of the ZAV and (2) the new composite zero air voids curve $\left(\mathrm{ZAV}_{\text {composite }}\right)$ as depicted in Fig. 4. The line of optimums is presented parallel to the $\mathrm{ZAV}_{\text {composite, which is steeper }}$ than the ZAV associated with a single $G_{s}$ (Fig. 4).

The specific shape of the relationship between total unit weight and water content for soils is described by two separate mechanisms: water addition and compaction of soil mass (Johnson and Sallberg 1960). A third mechanism that applies to compaction of wastes is the densification of the solids. For soils, a linear increase in $\gamma_{t}$ results from addition of water weight and a nonlinear increase from compaction resulting from improved particle packing efficiency at increasing moisture contents. At high $w$ (specifically, wet of optimum), water starts replacing solids and this replacement results in a decrease in unit weight with further increases in $w$. For wastes, the variation of $\gamma_{t}$ with $w$ is generally similar to that for soils. However, the decrease in $\gamma_{t}$ at high $w$ for wastes is not as prominent as that for soils because the relative difference between unit weight of water and unit weight of solids is lower for wastes than for soils. At relatively low compaction efforts and associated low $G_{s}$, the replacement of solids with water leads to a leveling off of $\gamma_{t}$ due to the relative similarity in unit weight of water and waste solids. At higher compaction efforts and associated higher $G_{s}$, the replacement of waste solids with water results in a decrease in $\gamma_{t}$ due to the higher difference between the $G_{s}$ of water and waste solids. Schematic trends for $\gamma_{t}$ 


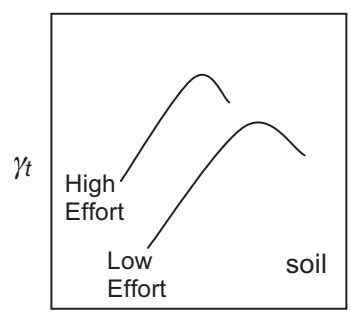

W

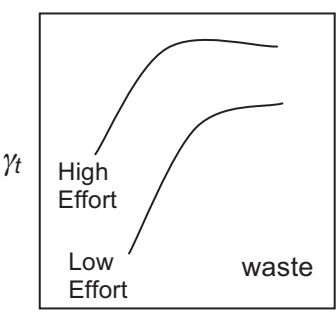

W
Fig. 5. Schematic plots of $\gamma_{t}$ versus $w$ for soil and waste

as a function of $w$ for soils and wastes are presented in Fig. 5. The trends in Fig. 5 for wastes were observed in the test program as presented in Wong (2009).

An alternative representation for waste compaction data is provided in a schematic in Fig. 6 as a means to interpret changes in total unit weight as a function of water content and compaction effort. A two-dimensional plot of $w$ versus $\gamma_{t}$ is sufficient for soils compacted at variable efforts, whereas a third axis is required for wastes to include the variation in $\gamma_{t}$ due to the increase of $G_{s}$ of the solids with compactive effort, which typically does not apply to soils. Fig. 6 provides perspective on the relative contribution of the addition of water, increase in $G_{s}$, and compaction on the resulting compacted unit weight. The three-dimensional (3D) plot allows for representative depiction of the results of waste compaction tests at variable compactive efforts. If this $3 \mathrm{D}$ plot were produced for soil compaction, it would have a similar appearance with the exception that the triangular wedge associated with increasing $G_{s}$ would not be present.

\section{Practical Implications}

Moisture addition during compaction can provide increased waste placement rates or extended service life for a landfill. The tipping fee at the field site is approximately $\$ 15$ per $8.9 \mathrm{kN}$ of incoming waste resulting in a daily tipping fee of approximately $\$ 44,000$. By moisture addition during compaction, 24,200 and 6,300 kN more waste can be placed daily in the same compacted volume in winter and summer, respectively (the values are calculated using the highest $\gamma_{\text {oper }}$ in the seasonal tests). For the option of increased waste intake, the daily tipping fees increase by $\$ 41,000$ and $\$ 11,000$ in winter and summer, respectively. The maximum cost for water addition is estimated to be approximately $\$ 1,900 /$ day (including equipment, operating costs, maintenance, and personnel) at the site (R. Bobeck, personal communication, 2009). Additional operational costs include equipment and personnel

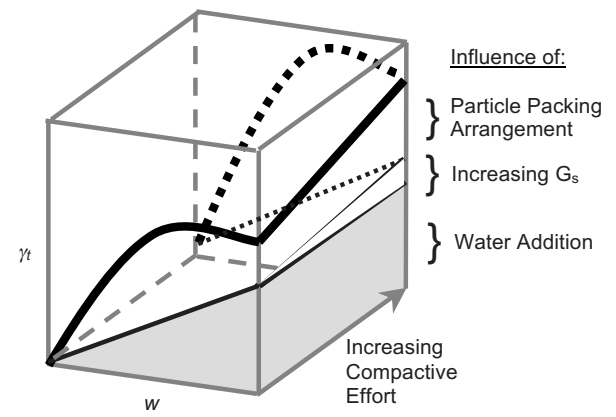

Fig. 6. Schematic 3D plot of waste compaction associated with placement and compaction of the added waste mass. Nevertheless, a significant net revenue increase from tipping fees is projected for the site due to moisture addition during compaction. Leachate also can be used for moisture addition reducing added costs. The tipping fees and leachate management costs are low at this site. Higher increases in revenue can be expected for sites with higher tipping fees and leachate management costs located in areas with similar climatic conditions. For the case of maintaining the same waste intake rate at the landfill, the design life of the facility would be extended by a factor of approximately 1.6 (allowing up to 10 years additional waste placement for the 18-year remaining baseline service life).

Significant long-term settlement of wastes are expected at MSW landfills (Edil et al. 1990). The additional volume generated provides extra space for waste placement or extended service life for a landfill. However, this additional volume may or may not be available for additional waste placement since regulatory agencies typically require rapid installation of final cover systems over cells that reach terminal heights prior to onset and/or completion of long-term settlements. Disposal of more waste at the time of waste placement guarantees that more wastes are actually placed within a given landfill volume. Also, higher initial unit weights of wastes due to moisture addition during compaction are expected to improve geomechanical stability of landfills.

\section{Summary and Conclusions}

This study was conducted to determine compaction characteristics of MSW in the laboratory and in the field. Effects of environmental (seasonal variation and temperature) and operational (moisture content, compactive effort, and compaction duration) conditions on compaction were investigated. Mechanisms of waste compaction were analyzed.

Laboratory tests were conducted on manufactured wastes with representative component fractions using modified and $4 \mathrm{X}$ modified effort. Field tests were conducted at a MSW landfill in Michigan by adding water to wastes on designated test plots using incoming wastes without any modifications to composition, size, or shape. Typical compaction equipment and procedures used at the site were employed in the test program. The compaction parameters were

- Laboratory: $\gamma_{d \max -\bmod }=5.2 \mathrm{kN} / \mathrm{m}^{3}, \quad w_{\text {opt-mod }}=65 \%$ and $\gamma_{d \max -4 \times \bmod }=6.0 \mathrm{kN} / \mathrm{m}^{3}, w_{\text {opt }-4 \times \bmod }=56 \%$;

- Field: $\gamma_{d \text { max-low }}=5.7 \mathrm{kN} / \mathrm{m}^{3}, \quad w_{\text {opt-low }}=70 \%$ and $\gamma_{d \text { max-high }}$ $=8.2 \mathrm{kN} / \mathrm{m}^{3}, w_{\text {opt-high }}=73 \%$;

- Field: $\gamma_{d \text { max-cold }}=8.2 \mathrm{kN} / \mathrm{m}^{3}, w_{\text {cold }}=79.5 \%$ and $\gamma_{d \text { max-warm }}$ $=6.1 \mathrm{kN} / \mathrm{m}^{3}, w_{\text {warm }}=70.5 \%$.

The field tests generally resulted in higher unit weights at higher water contents than the laboratory tests, even though at low efforts the laboratory and field data were generally similar. Soil testing procedures were effective for testing wastes in the laboratory. A hydration time of 16 to $24 \mathrm{~h}$ for wastes resulted in more uniform compaction curves than those for wastes compacted without hydration. Laboratory testing provides an effective means for evaluating trends in compaction characteristics of wastes, while field testing allows for identifying and ascertaining numerical values of significant compaction parameters on a field scale.

In the field, significant differences were observed in the moisture content of incoming wastes due to climatic conditions and seasonal waste stream. The addition of moisture to wastes resulted in increases in both dry and total unit weights above the 
average and season-specific baseline conditions. The newly introduced operational unit weight, determined as the quotient of total weight of incoming wastes and compacted volume, increased significantly with the addition of moisture. Moisture addition to wastes was more effective in winter than in summer due to the combined effects of dry initial conditions and some potential thawing and softening of incoming wastes. The average baseline dry unit weight generally could be obtained with sufficient duration of compaction ( $\geq 6 \mathrm{~min}$ ) for variable moisture conditions and high compactive effort resulted in short durations $(<6 \mathrm{~min})$.

The overall benefits of moisture addition to wastes include increased workability, increased unit weight, increased storage of incoming wastes, and reduced time required for compaction. The combined effects have significant environmental and economic implications for landfill operations.

\section{Acknowledgments}

This study was partially supported by the Office of Naval Research (Award No. N00014-05-1-0855). The cooperation of Riverview Land Preserve, and in particular, the assistance of Mr. Robert Bobeck and Mr. Edward Worrel are greatly appreciated. Mr. Nicolas Oettle and Mr. Matthew Gerpheide assisted with the laboratory test program.

\section{References}

Baker, J. A., and Eith, A. W. (2000). "The bioreactor landfill: Perspectives from an owner/operator." Proc., 14th GRI Conf., Hot Topics in Geosynthetics-I, Geosynthetic Institute (GSI), Folsom, Pa., 27-39.

Edil, T. B., Ranguette, V. J., and Wuellner, W. W. (1990). "Settlement of municipal refuse." Geotechnics of waste fills-Theory and practice, ASTM STP 1070, A. Landva and D. Knowles, eds. ASTM, West Conshohocken, Pa., 225-239.

Fang, H.-Y. (1997). Introduction to environmental geotechnology, CRC, Boca Raton, Fla.

Gabr, M. A., and Valero, S. N. (1995). "Geotechnical properties of municipal solid waste." Geotech. Test. J., 18(2), 241-251.
Ham, R. K., Reinhardt, J. J., and Sevick, G. W. (1978). "Density of milled and unprocessed refuse." J. Envir. Engrg. Div., 104(EE1), 109-125.

Harris, M. R. R. (1979). "Geotechnical characteristics of landfilled domestic refuse." The Engineering Behaviour of Industrial and Urban Fill: Proc. of the Symp. held at the Univ. of Birmingham, Midland Geotechnical Society, Univ. of Birmingham, Birmingham, England, B1-B10.

Haydar, M. M., and Khire, M. V. (2007). "Leachate recirculation using permeable blankets in engineered landfills." J. Geotech. Geoenviron. Eng., 133(4), 360-371.

Hudson, A. P., White, J. K., Beaven, R. P., and Powrie, W. (2004). "Modeling the compression behavior of landfilled domestic waste." Waste Manage., 24, 259-269.

Itoh, T., et al. (2005). "Mechanical properties of municipal waste deposits and ground improvement." Proc. of the 16th Int. Conf. on Soil Mechanics and Geotechnical Engineering, Vol. 4, Millpress Science Publishers, Rotterdam, The Netherlands, 2273-2276.

Johnson, A. W., and Sallberg, J. R., (1960). Factors that influence field compaction of soils, Bulletin 272, Highway Research Board, National Academy of Sciences, National Research Council, Washington, D.C.

Phaneuf, R. J. (2000). "Bioreactor landfills: Regulatory issues." Proc., 14th GRI Conf., Hot Topics in Geosynthetics-I, Geosynthetic Institute (GSI), Folsom, Pa., 9-26.

Qian, X., Koerner, R. M., and Gray, D. H. (2002). Geotechnical aspects of landfill design and construction, Prentice-Hall, Upper Saddle River, N.J.

Reddy, K. R., Gangathulasi, J., Parakalla, N. S., Hettiarachchi, H., Bogner, J. E., and Lagier, T. (2009). "Compressibility and shear strength of municipal solid waste under short-term leachate recirculation operations." Waste Manage. Res., 27, 578-587.

U.S. EPA. (2008). "Municipal solid waste generation, recycling, and disposal in the United States: Facts and figures for 2006." 〈http:// www.epa.gov/osw/nonhaz/municipal/pubs/msw06.pdf $\rangle$ (April 20, 2008).

U.S. EPA. (2009). "Municipal solid waste in the United States: 2007 facts and figures." 〈http://www.epa.gov/osw/nonhaz/municipal/pubs/ msw07-rpt.pdf $\rangle$ (April 19, 2009).

Von Stockhausen, S. A. (2007). "Optimization of waste compaction practices for landfills." MS thesis, California Polytechnic State Univ., San Luis Obispo, Calif.

Wong, W. W. (2009). "Investigation of the geotechnical properties of municipal solid waste as a function of placement conditions." MS thesis, California Polytechnic State Univ., San Luis Obispo, Calif. 